\title{
Synthesis, Crystal Structures, Molecular Docking, and Urease Inhibitory Activity of Transition Metal Complexes with 2-[4-(4-Fluorophenyl)piperazin-1-yl]acetic Acid
}

\author{
Zhi-Jian Chen, Chun-Na Xu, Jin-Long Zhu, Dan-Dan Yang, \\ Shan-Shan Zhao, Ya-Nan Chen and Shao-Song Qian \\ School of Life Sciences, Shandong University of Technology, Zibo 255049, P. R. China \\ * Corresponding author: E-mail: Shao-Song Qian, E-mail:sdutqss@163.com \\ Tel.: 0086-533-2780271; Fax: 0086-533-2781329.
}

Received: 07-11-2015

\begin{abstract}
Two novel mononuclear complexes, $\left[\mathrm{Cu}(\mathbf{L})_{2}\left(\mathrm{H}_{2} \mathrm{O}\right)\right] \cdot 2 \mathrm{H}_{2} \mathrm{O}(\mathbf{1})$ and $\left[\mathrm{Ni}(\mathbf{L})_{2}\left(\mathrm{H}_{2} \mathrm{O}\right)_{2}\right](\mathbf{2})(\mathbf{H L}=2$-[4-(4-fluorophenyl)piperazin-1-yl]acetic acid) were synthesized and structurally determined by single-crystal X-ray diffraction. Their inhibitory activities were tested in vitro against jack bean urease. Molecular docking was investigated to determine the probable binding mode. The experimental values and docking simulation exhibited that complex $\mathbf{1}$ had better inhibitory activity than the positive reference acetohydroxamic acid (AHA), showing $\mathrm{IC}_{50}$ value of $0.15 \pm 0.08 \mu \mathrm{M}$, while 2 showed no inhibitory activity.
\end{abstract}

Keywords: Complexes, crystal structure, urease inhibitor, molecular docking

\section{Introduction}

Urease is a nickel-containing metalloenzyme, which can be widely found in various fungus, germs and plants, ${ }^{1}$ catalyzing the hydrolysis of urea into ammonia and carbamate. ${ }^{2,3}$ Comparing the sequences of jack bean urease and bacteria urease suggests that these two different kinds of urease may have a common evolutionary origin. ${ }^{4}$ The catalytic sites in jack bean urease and $H$. pylori urease display highly conserved amino acid residues, indicating the ureases may have the same catalytic mechanism. In addition, it is a major cause of pathologies induced by Helicobacter pylori (H. pylori) as it allows the bacteria to survive in the extremely acidic environment of stomach during colonization. ${ }^{5-8}$ Meanwhile, the reaction catalyzed by urease will increase the $\mathrm{pH}$ value, which is a virulency factor in pathogens responsible for the development of kidney stones, pyelonephritis, peptic ulcers, and other diseases. ${ }^{9,10}$ Therefore, the restriction of the activity of urease is an important goal to pursue.

Recently, a compound synthesized by Negar ${ }^{11}$ containing 3-methoxybenzylpiperazine pendant demonstrated strong urea enzyme inhibitory activity. We are interested in finding metal complexes which possess potential urease enzyme inhibitory activities. Therefore, 2-[4-(4fluorophenyl)piperazin-1-yl]acetic acid (HL) and two metal complexes bearing $\mathbf{L}$ were synthesized. The structures of $\left[\mathrm{Cu}(\mathbf{L})_{2}\left(\mathrm{H}_{2} \mathrm{O}\right)\right] \cdot 2 \mathrm{H}_{2} \mathrm{O}(\mathbf{1})$ and $\left[\mathrm{Ni}(\mathbf{L})_{2}\left(\mathrm{H}_{2} \mathrm{O}\right)_{2}\right](\mathbf{2})$ were characterized by $\mathrm{X}$-ray diffraction. The inhibitory activity evaluation of the complexes $\mathbf{1}$ and $\mathbf{2}$ was performed against jack bean urease in vitro. Docking simulation was investigated from the docking analysis using the AUTODOCK 4.2 program to determine the probable binding mode.

\section{Experimental}

\section{1. Materials and Methods}

All chemicals and reagents used in the current study were of analytical grade. Urease (from jack beans, type III, activity 34310 units/mg solid), HEPES buffer, and urea were purchased from Sigma-Aldrich Co. (St. Louis, MO, USA). $\mathrm{Cu}\left(\mathrm{NO}_{3}\right)_{2} \cdot 3 \mathrm{H}_{2} \mathrm{O}, \mathrm{Ni}\left(\mathrm{NO}_{3}\right)_{2} \cdot 6 \mathrm{H}_{2} \mathrm{O}, 1$-(4-fluorophenyl)piperazine, DMSO, and bromoacetic acid were purchased from Aladdin Chemistry Co. Ltd (Shanghai) and used without further purification. All other chemicals and solvents were purchased from Aldrich and used as re- 
ceived. Distilled water was used for all procedures. Elemental analyses $(\mathrm{C}, \mathrm{H}$, and $\mathrm{N})$ were performed using a Perkin-Elmer 240 elemental analyzer. IR spectra were recorded on a FT-IR Nicolet 5700 Spectrometer from 4000 to $400 \mathrm{~cm}^{-1}$. The enzyme inhibitory activity was measured on a Bio-Tek Synergy ${ }^{\mathrm{TM}}$ HT Microplate reader.

\section{2. General Synthetic Method for the Preparation of the HL}

1-(4-Fluorophenyl)piperazine $(1.80 \mathrm{~g}, 0.010 \mathrm{~mol})$ and bromoacetic acid $(1.67 \mathrm{~g}, 0.012 \mathrm{~mol})$ were added into $50 \mathrm{~mL}$ ethanol which containing $0.6 \mathrm{~mol} / \mathrm{L}$ potassium hydroxide. The resulting mixture was refluxed for $14 \mathrm{~h}$ at $75^{\circ} \mathrm{C}$ and after cooling the solvent was neutralized with hydrochloric acid to form the precipitate, which was isolated by filtration from ethanol to give pure HL. Yield was $88 \%$.

\section{3. General Synthetic Method for the Complexes}

HL $(0.2 \mathrm{mmol})$ in methanol solution $(5 \mathrm{~mL})$ was added to aqueous solution $(5 \mathrm{~mL})$ of the corresponding metal acetate $(0.2 \mathrm{mmol})$. The resulting solution was stirred for $15 \mathrm{~min}$ at room temperature and then filtered. The filtrate was left to stand at room temperature for a few days to give the corresponding block crystals suitable for X-ray diffraction analysis. The crystals were isolated, washed three times with methanol and dried in a vacuum desiccator. The elemental analyses and characteristic IR data for the complexes were as follows:

(1) $\left[\mathrm{Cu}(\mathbf{L})_{2}\left(\mathrm{H}_{2} \mathrm{O}\right)\right] \cdot 2 \mathrm{H}_{2} \mathrm{O}$ Yield: $63 \%$; blue crystal. Calc. for $\mathrm{C}_{24} \mathrm{H}_{34} \mathrm{~F}_{2} \mathrm{~N}_{4} \mathrm{O}_{7} \mathrm{Cu}: \mathrm{C}, 47.39 ; \mathrm{H}, 8.29$; N, 9.21; Found: C, 47.63; H, 8.25; N, 9.26. Characteristic IR data $\left(\mathrm{KBr}, \mathrm{cm}^{-1}\right)$ : 3284, 2926, 2839, 1596, 1511, 1417, 1328, 931, 819, 737.

(2) $\left[\mathrm{Ni}(\mathrm{L})_{2}\left(\mathrm{H}_{2} \mathrm{O}\right)_{2}\right]$ Yield: 60\%; aquamarine crystal. Calc. for $\mathrm{C}_{24} \mathrm{H}_{32} \mathrm{~F}_{2} \mathrm{~N}_{4} \mathrm{O}_{6} \mathrm{Ni}$ : C, 49.25; H, 8.27; N, 9.57; Found: C, 49.50; H, 8.23; N, 9.62. Characteristic IR data $\left(\mathrm{KBr}, \mathrm{cm}^{-1}\right): 3443,2829,1636,1512,1456,1326,1044$, 932, 826, 738 .

\section{4. Crystal Structure Determination}

Single crystals of complexes $\mathbf{1}$ and $\mathbf{2}$ were mounted on a thin glass fiber at room temperature. The reflection data were collected on a Bruker D8 VENTURE PHOTON diffractometer with graphite monochromatic Mo$\mathrm{K}_{\alpha}$ radiation $(\lambda=0.71073 \AA)$ using the generic omega scan technique. The structures were solved by direct methods and refined on $F^{2}$ by full matrix least-squares with SHELXS-97 program. ${ }^{13,14}$ All of the non-hydrogen atoms were refined anisotropically. The water $\mathrm{H}$ atoms were located in a difference Fourier map and refined freely. The remaining $\mathrm{H}$ atoms were placed in idealized positions and constrained to ride on their parent atoms. Owing to too much water molecules in the asymmetric unit, many numbers of refined parameters may have been limited deliberately leading to the R Flagged nonhydrogen atoms. The crystallographic data are summarized in Table 1.

Table 1 Crystallographic data for complexes $\mathbf{1}$ and $\mathbf{2}$.

\begin{tabular}{lcc}
\hline & $\mathbf{1}$ & $\mathbf{2}$ \\
\hline Chemical formula & $\mathrm{C}_{24} \mathrm{H}_{34} \mathrm{~F}_{2} \mathrm{~N}_{4} \mathrm{O}_{7} \mathrm{Cu}$ & $\mathrm{C}_{24} \mathrm{H}_{32} \mathrm{~F}_{2} \mathrm{~N}_{4} \mathrm{O}_{6} \mathrm{Ni}$ \\
Formula Weight & 592.10 & 569.23 \\
Crystal System & Monoclinic & Triclinic \\
Space group & $P 2_{1} / \mathrm{c}$ & $P \hat{1}$ \\
$a(\AA)$ & $27.5082(16)$ & $6.6508(6)$ \\
$b(\AA)$ & $9.2312(5)$ & $7.2655(6)$ \\
$c(\AA)$ & $20.6915(12)$ & $15.3900(14)$ \\
$\alpha\left(^{\circ}\right)$ & 90 & $95.281(3)$ \\
$\beta\left({ }^{\circ}\right)$ & $92.558(2)$ & $95.647(3)$ \\
$\gamma\left({ }^{\circ}\right)$ & 90 & $115.921(2)$ \\
$V\left(\AA^{3}\right)$ & $5249.0(5)$ & $657.99(10)$ \\
$Z$ & 8 & 1 \\
$\mu\left(\mathrm{Mo}^{\circ}-\mathrm{K}_{\alpha}\right)\left(\mathrm{mm}^{-1}\right)$ & 0.897 & 0.797 \\
$R_{1}, w R_{2}[I>2 \sigma(I)]$ & $0.0426,0.1050$ & $0.0374,0.0980$ \\
$\rho_{\mathrm{c}}\left(\mathrm{g} \mathrm{cm}^{-3}\right)$ & 1.498 & 1.436 \\
$F(000)$ & 2472 & 298 \\
$\mathrm{GOF}$ on $F^{2}$ & 1.02 & 1.10 \\
\hline
\end{tabular}

\section{5. Measurement of Jack Bean Urease Inhibitory Activity}

The measurement of urease inhibitory activity was carried out according to the literature reported before. ${ }^{15}$ The assay mixture consisted of $25 \mu \mathrm{L}$ of jack bean urease (40 kU/L) (dissolved in distilled water) and $25 \mu \mathrm{L}$ of the acquired complexes of different concentrations (dissolved in $\mathrm{DMSO} / \mathrm{H}_{2} \mathrm{O}$ mixture $\left.(1: 1 \mathrm{v} / \mathrm{v})\right)$ was pre-incubated for $1 \mathrm{~h}$ at $37^{\circ} \mathrm{C}$ in a 96-well plates. Following, the addition of $200 \mu \mathrm{L}$ of $100 \mathrm{mM}$ HEPES buffer $\mathrm{pH} 6.8$ containing $500 \mathrm{mM}$ urea and $0.002 \%$ phenol red to each well and then incubated at $37{ }^{\circ} \mathrm{C} .{ }^{16}$ Finally, the reaction was measured at $570 \mathrm{~nm}$ by a Microplate reader (Bio-Tek Synergy ${ }^{\mathrm{TM}}$ HT, Instruments, Inc. USA), which was required to produce enough ammonium carbonate to raise the $\mathrm{pH}$ of a HEPES buffer from 6.8 to $7.7 .{ }^{17}$ The results were analyzed using SPSS 19.0 (International Business Machines Corporation, Armonk, NY, USA) program and showed in Table 4.

\section{6. Molecular Docking}

Molecular docking of complexes $\mathbf{1}$ and $\mathbf{2}$ with the active site of jack bean urease (3LA4) was performed by the AUTODOCK 4.2 program suite. The structures of complexes in docking protocol were used as crystal struc- 
tures. The graphical user interface AutoDockTools was intended to install the enzymes: all hydrogens were added at every inhibitor enzyme interaction, Gasteiger charges were calculated and non-polar hydrogens were merged to carbon atoms. The Ni initial parameters are set as $r=$ $1.170 \AA, q=+2.0$, and Vander Waals well depth of 0.100 $\mathrm{kcal} / \mathrm{mol}$. The 3D structures of ligand molecules were saved in Mol2 format with the assistance of the program MERCURY. The partial charges of Mol2 file were further modified by using the ADT package so that the charges of the non-polar hydrogen atoms would be assigned to the atom to which the hydrogen is attached..$^{18}$ The resulting file was saved as pdbqt file.

The docking input files were generated by $\mathrm{Au}$ toDockTools program. A grid box size of $60 \times 60 \times 60$ pointing in $\mathrm{x}, \mathrm{y}$ and $\mathrm{z}$ directions were built. The maps were centered on the Ni842 atom in the catalytic site of the protein in all docking. The binding mode of potential urease inhibitor complex 1 with 3LA4 was displayed in Figure 7 and Figure 8.

\section{Results and Discussion}

\section{1. Synthesis and Spectroscopic Studies}

HL was prepared by electrophilic substitution reaction between 1-(4-fluorophenyl)piperazine and bromoacetic acid according to the method of Sadashiva with suitable modification (Scheme 1). ${ }^{12}$ The yield of $\mathbf{H L}$ was $88 \%$. The ligand was stable and could dissolve in the polar solvent such as methanol and $N, N$-dimethylformamide (DMF). Generally, treatment of the ligand with salts $\mathrm{Cu}\left(\mathrm{NO}_{3}\right)_{2} \cdot 3 \mathrm{H}_{2} \mathrm{O}$ and $\mathrm{Ni}\left(\mathrm{NO}_{3}\right)_{2} \cdot 6 \mathrm{H}_{2} \mathrm{O}$ with $2: 1$ molar ratio at ambient temperature led to the formation of the complexes. Crystal of complexes suitable for X-ray diffraction were isolated after slow evaporation of the solvent over several days.

The IR spectra of these complexes were similar. They all show broad band ranging from $3450 \mathrm{~cm}^{-1}$ to $3200 \mathrm{~cm}^{-1}$ indicating the $\mathrm{O}-\mathrm{H}$ stretching of the water molecules. The separation value $\Delta v\left[v_{\mathrm{as}}\left(\mathrm{COO}^{-}\right)-v_{\mathrm{s}}\left(\mathrm{COO}^{-}\right)\right]$ of the carboxylic based complex can be used to distin-

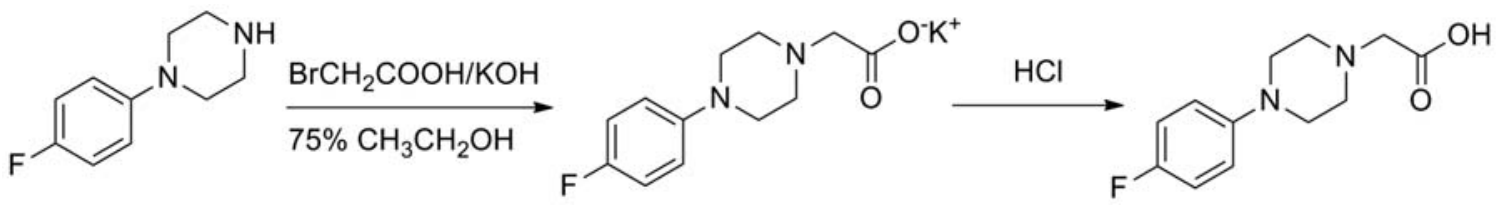

Scheme 1. Synthetic routes to 2-[4-(4-fluorophenyl)piperazin-1-yl]acetic acid.

Table 2. Important bond distances $(\AA)$ and angles $\left(^{\circ}\right)$ for complexes $\mathbf{1}$ and $\mathbf{2}$

\begin{tabular}{|c|c|c|c|}
\hline \multicolumn{4}{|l|}{1} \\
\hline$\overline{\mathrm{Cu} 1-\mathrm{O} 1}$ & $1.9260(15)$ & $\mathrm{Cu} 1-\mathrm{O} 3$ & $1.9528(15)$ \\
\hline $\mathrm{Cu} 1-\mathrm{O} 6 \mathrm{~W}$ & $2.2336(16)$ & $\mathrm{Cu} 1-\mathrm{N} 2$ & $2.0310(17)$ \\
\hline $\mathrm{Cu} 1-\mathrm{N} 3$ & $2.0330(17)$ & $\mathrm{Cu} 2-\mathrm{O} 5$ & $1.9410(15)$ \\
\hline $\mathrm{Cu} 2-\mathrm{O} 7$ & $1.9322(16)$ & $\mathrm{Cu} 2-\mathrm{O} 5 \mathrm{~W}$ & $2.1974(17)$ \\
\hline $\mathrm{Cu} 2-\mathrm{N} 5$ & 2.0333(19) & $\mathrm{Cu} 2-\mathrm{N} 7$ & $2.0399(17)$ \\
\hline $\mathrm{O} 1-\mathrm{Cu} 1-\mathrm{O} 3$ & $164.58(7)$ & O1-Cu1-O6W & $100.43(7)$ \\
\hline $\mathrm{O} 1-\mathrm{Cu} 1-\mathrm{N} 2$ & $84.21(7)$ & $\mathrm{O} 1-\mathrm{Cu} 1-\mathrm{N} 3$ & $94.59(7)$ \\
\hline O3-Cu1-O6W & $94.95(7)$ & $\mathrm{O} 3-\mathrm{Cu} 1-\mathrm{N} 2$ & $94.87(6)$ \\
\hline $\mathrm{O} 3-\mathrm{Cu} 1-\mathrm{N} 3$ & $83.43(6)$ & O6W-Cu1-N2 & $97.23(7)$ \\
\hline O6W-Cu1-N3 & $93.53(7)$ & $\mathrm{N} 2-\mathrm{Cu} 1-\mathrm{N} 3$ & $169.22(7)$ \\
\hline $\mathrm{O} 5-\mathrm{Cu} 2-\mathrm{O} 7$ & $166.71(8)$ & O5-Cu2-O5W & $99.18(7)$ \\
\hline O5-Cu2-N5 & $83.71(7)$ & O5-Cu2-N7 & $95.64(7)$ \\
\hline $\mathrm{O} 5 \mathrm{~W}-\mathrm{Cu} 2-\mathrm{O} 7$ & $94.03(7)$ & $\mathrm{O} 5 \mathrm{~W}-\mathrm{Cu} 2-\mathrm{N} 5$ & $98.90(7)$ \\
\hline $\mathrm{O} 5 \mathrm{~W}-\mathrm{Cu} 2-\mathrm{N} 7$ & $96.11(7)$ & $\mathrm{O} 7-\mathrm{Cu} 2-\mathrm{N} 5$ & $92.91(7)$ \\
\hline $\mathrm{O} 7-\mathrm{Cu} 2-\mathrm{N} 7$ & $84.28(7)$ & N5-Cu2-N7 & $164.89(7)$ \\
\hline \multicolumn{4}{|l|}{2} \\
\hline$\overline{\mathrm{Ni1}-\mathrm{O} 1 \mathrm{~W}}$ & $2.0639(12)$ & Ni1-O2 & $2.002(2)$ \\
\hline Ni1-N2 & $2.2595(19)$ & Ni1-O1WA & $2.0639(12)$ \\
\hline $\mathrm{Ni1}-\mathrm{O} 2 \mathrm{~A}$ & $2.002(2)$ & Ni1-N2A & 2.2595(19) \\
\hline O1W-Ni1-O2 & $87.11(6)$ & O1W-Ni1-N2 & $90.54(6)$ \\
\hline O1W-Ni1-O1WA & 180.00 & O1W-Ni1-O2A & $92.89(6)$ \\
\hline O1W-Ni1-N3 & $96.27(15)$ & O1W-Ni1-N2A & $89.46(6)$ \\
\hline $\mathrm{O} 2-\mathrm{Ni} 1-\mathrm{N} 2$ & $80.88(7)$ & O2-Ni1-N2A & $99.12(7)$ \\
\hline $\mathrm{O} 2-\mathrm{Ni1}-\mathrm{O} 2 \mathrm{~A}$ & 180.00 & N2-Ni1-N2A & 180.00 \\
\hline
\end{tabular}


guish the coordination mode of the carboxyl group. The $\Delta v<200 \mathrm{~cm}^{-1}$ indicates the bidentate mode, whereas $\Delta v>$ $200 \mathrm{~cm}^{-1}$ indicates the monodentate mode. The asymmetric stretching mode $v_{\text {as }}\left(\mathrm{COO}^{-}\right)$is located around 1616 $\mathrm{cm}^{-1}$, while the strong symmetric stretching mode $v_{\mathrm{s}}\left(\mathrm{COO}^{-}\right)$were clearly visible around $1410 \mathrm{~cm}^{-1}$ for complexes 1 and 2. Therefore, the $\Delta v$ values about $206 \mathrm{~cm}^{-1}$ means that ligands in compounds $\mathbf{1}$ and $\mathbf{2}$ have monodentate binding mode. ${ }^{19,20}$ The $\mathrm{C}-\mathrm{N}$ stretching vibration was noticed in the region of $1330-1300 \mathrm{~cm}^{-1}$. $^{21}$

\section{2. X-ray Structure Analysis}

The related bond distances and bond angles data was listed in Table 2. The data of hydrogen-bonds was exhibited in Table 3. The ORTEP plots of the compounds were presented in Figure 1 and Figure 2. which ensures the planarity of equatorial plane. The axial $\mathrm{Cu}-\mathrm{O}$ average distance $(2.197 \AA)$ is longer than the equatorial $\mathrm{Cu}-\mathrm{O}$ average distance $(1.938 \AA$ ) and $\mathrm{Cu}-\mathrm{N}$ average distance (2.033 $\AA$ ), showing the stretched tetrahedroid surrounding the $\mathrm{Cu}$ (II) center. Compared with the other piperazine- $\mathrm{Cu}$ (II) complexes, the $\mathrm{Cu}-\mathrm{O}$ carboxyl bond length $(1.938 \AA)$ is similar to the $\mathrm{Cu}-\mathrm{O}$ carbonyl bond length (1.923 $\AA$ ), and $\mathrm{Cu}-\mathrm{N}$ bond length $(2.033 \AA)$ in complex $\mathbf{1}$ is also similar to the other piperazine- $\mathrm{Cu}$ (II) complexes. $^{23}$

Water is a hydrogen bond donor (and acceptor). ${ }^{26}$ Complex 1 presents enhanced hydrogen-bonding framework in the solid state (Table 3). Two non-coordinational water molecules (O1W and $\mathrm{O} 3 \mathrm{~W})$ are forming a dimer using $\mathrm{O} 1 \mathrm{~W}-\mathrm{H} 1 \mathrm{~W} 1 \cdots \mathrm{O} 3 \mathrm{~W}^{\mathrm{iii}}$ (symmetry code: (iii) $-x+1, y$ $+1 / 2,-z+3 / 2$ ). As shown in Figure 2, these dimers are located between the adjacent mononuclear units, and serve

Table 3. Hydrogen-bonds $\left(\AA,^{\circ}\right)$ for complexes $\mathbf{1}$ and $\mathbf{2}$

\begin{tabular}{|c|c|c|c|c|}
\hline Hydrogen bonds & D-H(̊̊) & $\mathbf{H} \cdots \mathbf{A}(\AA)$ & $\mathbf{D} \cdots \mathbf{A}(\AA)$ & D-H $\cdots A\left({ }^{\circ}\right)$ \\
\hline \multicolumn{5}{|c|}{ Complex 1} \\
\hline 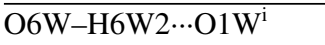 & 0.820 & 1.984 & 2.755 & 156.39 \\
\hline O6W-H6W $1 \cdots \mathrm{O} 1^{\mathrm{ii}}$ & 0.827 & 2.033 & 2.859 & 176.46 \\
\hline $\mathrm{O} 1 \mathrm{~W}-\mathrm{H} 1 \mathrm{~W} 1 \cdots \mathrm{O} 3 \mathrm{~W}^{\mathrm{iii}}$ & 0.846 & 1.933 & 2.753 & 162.92 \\
\hline $\mathrm{O} 3 \mathrm{~W}-\mathrm{H} 3 \mathrm{~W} 2 \cdots \mathrm{N} 4^{\mathrm{iv}}$ & 0.856 & 2.161 & 2.972 & 158.13 \\
\hline $\mathrm{O} 1 \mathrm{~W}-\mathrm{H} 1 \mathrm{~W} 2 \cdots \mathrm{O} 3^{\mathrm{v}}$ & 0.847 & 2.489 & 3.229 & 146.41 \\
\hline $\mathrm{O} 1 \mathrm{~W}-\mathrm{H} 1 \mathrm{~W} 2 \cdots \mathrm{O} 4^{\mathrm{v}}$ & 0.847 & 2.109 & 2.900 & 155.31 \\
\hline $\mathrm{O} 3 \mathrm{~W}-\mathrm{H} 3 \mathrm{~W} 1 \cdots \mathrm{O} 2$ & 0.854 & 2.418 & 2.909 & 117.25 \\
\hline \multicolumn{5}{|c|}{$\begin{array}{l}\text { Symmetry transformations used to generate equivalent atoms: (i) } x, y-1, z \text {; (ii) }-x+1, y-1 / 2,-z+3 / 2 \text {; (iii) }-x+1 \text {, } \\
\qquad y+1 / 2,-z+3 / 2 \text {; (iv) } x,-y+1 / 2, z-1 / 2 ; \text { (v) }-x+1,-y+1,-z+2\end{array}$} \\
\hline \multicolumn{5}{|c|}{ Complex 2} \\
\hline$\overline{\mathrm{O} 1 \mathrm{~W}-\mathrm{H} 1 \mathrm{~W} 1 \cdots \mathrm{O} 1^{\mathrm{vi}}}$ & 0.820 & 1.906 & 2.705 & 164.63 \\
\hline O1WA-H1W1A ‥O1A ${ }^{\mathrm{vi}}$ & 0.820 & 1.906 & 2.705 & 164.63 \\
\hline $\mathrm{O} 1 \mathrm{~W}-\mathrm{H} 1 \mathrm{~W} 2 \cdots \mathrm{O} 1^{\mathrm{vii}}$ & 0.836 & 1.884 & 2.710 & 169.92 \\
\hline 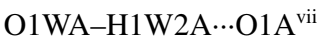 & 0.836 & 1.884 & 2.710 & 169.92 \\
\hline
\end{tabular}

\section{2. 1. Crystal Structure of Complex $\left[\mathrm{Cu}(\mathrm{L})_{2}\left(\mathrm{H}_{2} \mathrm{O}\right)\right] \cdot \mathbf{2} \mathrm{H}_{2} \mathrm{O}(\mathbf{1})$}

Complex 1 crystallized in the monoclinic space group $P 2_{1} / \mathrm{c}$. As shown in Figure 1, the asymmetric unit of 1 contains two complex molecules. The coordination geometry around the $\mathrm{Cu}(\mathrm{II})$ center is distorted rectangular pyramid $(\tau=0.08) .{ }^{22}$ Moreover, $\mathbf{L}$ behaves as a bidentate ligand that results in forming a novel distorted five-membered heterocyclic ring around copper ion. These two five-membered rings were not coplanar, the dihedral angle between these two planes is $3.672(65)^{\circ}$. The equatorial plane is surrounded by two O-atom donors (O1 and O3) and two $\mathrm{N}$-atom donors ( $\mathrm{N} 2$ and $\mathrm{N} 3$ ) from two $\mathbf{L}$ ligands, while the axial positions are occupied by $\mathrm{O}$-atom donors (O6W) from one coordinated water molecule. In addition, the sum of the equatorial angles $\mathrm{O} 1-\mathrm{Cu} 1-\mathrm{N} 3$, N3-Cu1-O3, O3-Cu1-N2 and N2-Cu1-O1 for complex $\mathbf{1}\left(\approx 357.10^{\circ}\right)$ is very close to the ideal value $\left(360.00^{\circ}\right)$,

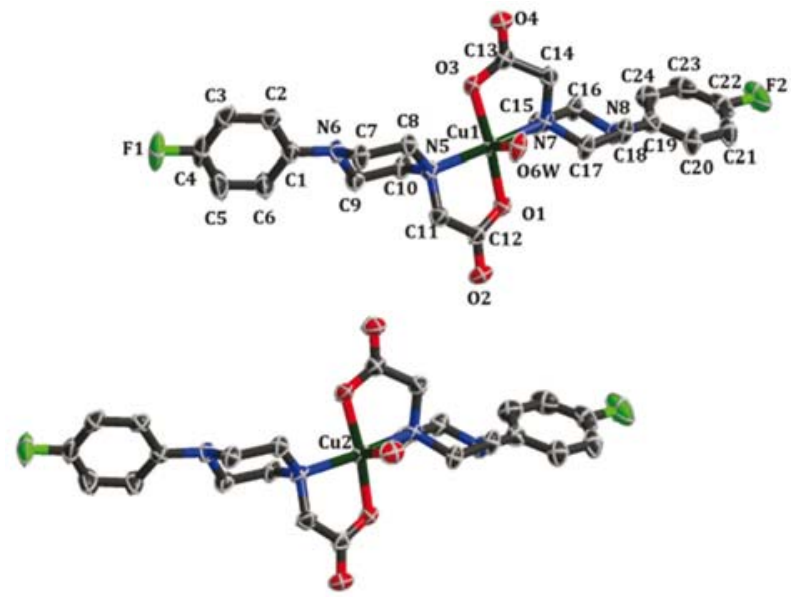

Fig. 1. Molecular diagram for complex 1 showing the atom-labeling scheme. The free water molecules and hydrogen atoms are omitted for clarity. Displacement ellipsoids are drawn at the $50 \%$ probability level. 
as hydrogen bonding donator linking these mononuclear units into infinite single-chain structure along $\mathrm{c}$ axis via $\mathrm{O} 1 \mathrm{~W}-\mathrm{H} 1 \mathrm{~W} 2 \cdots \mathrm{O}^{\mathrm{v}}{ }^{\mathrm{v}}, \mathrm{O} 1 \mathrm{~W}-\mathrm{H} 1 \mathrm{~W} 2 \cdots \mathrm{O} 4^{\mathrm{v}}$ (symmetry code: (v) $-x+1,-y+1,-z+2$ ), $\mathrm{O} 3 \mathrm{~W}-\mathrm{H} 3 \mathrm{~W} 2 \cdots \mathrm{N} 4^{\mathrm{iv}}$ (symmetry code: (iv) $x,-y+1 / 2, z-1 / 2$ ) and a strong intramolecular hydrogen bond $\mathrm{O} 3 \mathrm{~W}-\mathrm{H} 3 \mathrm{~W} 1 \cdots \mathrm{O} 2$. These supramolecular chains stack in a interleaved fashion in $b c$ plane, the hydrogen bonds exist between the carboxyl group of ligand $\mathbf{L}$ and the oxygen atom of coordinated water molecule to form intermolecular O6W-H6W2 $\cdots \mathrm{O} 1 \mathrm{~W}^{\mathrm{i}}$

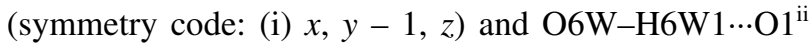
(symmetry code: (ii) $-x+1, y-1 / 2,-z+3 / 2$ ) hydrogen bonding interaction, leading to the construction of $2 \mathrm{D}$ supramolecular sheet in the $b c$ plane (Figure 3 ).

\section{2. 2. Crystal Structure of Complex $\left[\mathrm{Ni}(\mathrm{L})_{2}\left(\mathrm{H}_{2} \mathrm{O}\right)_{2}\right](2)$}

Complex 2 crystallized in the triclinic space group $P \hat{1}$. In the crystal structure of $\mathbf{2}$, the asymmetric unit contains one molecule. As shown in Figure 4, the central nickel ion is six-coordinate, which lies on the inversion center. It adopts a pseudo-octahedral coordination environ- ment, ${ }^{25}$ which defined by two nitrogen donors and two oxygen donors from two ligand molecules in the equatorial planet. The sum of the equatorial angles $\mathrm{O} 2-\mathrm{Ni} 1-\mathrm{N} 2$, $\mathrm{N} 2-\mathrm{Ni1}-\mathrm{O} 2 \mathrm{~A}, \mathrm{O} 2 \mathrm{~A}-\mathrm{Ni1}-\mathrm{N} 2 \mathrm{~A}$ and $\mathrm{N} 2 \mathrm{~A}-\mathrm{Ni1}-\mathrm{O} 2$ for complex $2\left(=360.00^{\circ}\right)$ is equal to the ideal value $\left(360.00^{\circ}\right)$, which ensures the planarity of equatorial plane. Unlike complex 1, these two newly formed five-membered rings were coplanar, the dihedral angle is $0.00(63)^{\circ}$. The axial positions are occupied by $\mathrm{O}$-atom donors $(\mathrm{O} 1 \mathrm{~W}$ and O1WA) from two coordinated water molecules. The axial Ni-O average distance $(2.064 \AA)$ is shorter than the equatorial $\mathrm{Ni}-\mathrm{N}$ average distance $(2.260 \AA)$, showing the squashed octahedron surrounding the Ni(II) center. The $\mathrm{Ni}-\mathrm{O}$ and $\mathrm{Ni}-\mathrm{N}$ distance were all similar to those reported values of $\mathrm{Ni}(\mathrm{II})$ complexes. $^{26}$

Like complex $\mathbf{1}$, the adjacent molecules are forming infinite one-dimensional catenulate structure through

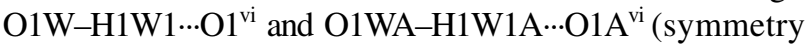
code: (vi) $-x+2,-y,-z+1$ ) intermolecular hydrogen bonds (Figure 5). These contiguous chains stack in a faceto-face fashion in $a b$ plane, the hydrogen bonds exist between the carboxyl group of ligand $\mathbf{L}$ and the oxygen atom of coordinated water molecule to form intermolecular

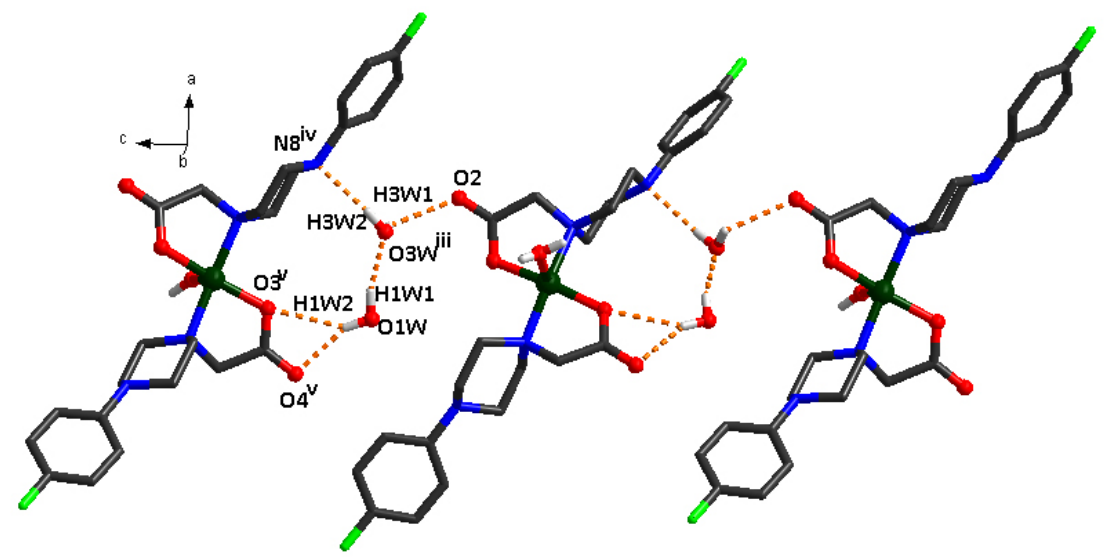

Fig. 2. the hydrogen-bond-driven $1 \mathrm{D}$ chain extended in crystallographic $c$ axis of $\mathbf{1}$. [Symmetry codes: (iii) $-x+1, y+1 / 2,-z+3 / 2$; (iv) $x,-y+1 / 2$, $z-1 / 2 ;(\mathrm{v})-x+1,-y+1,-z+2]$

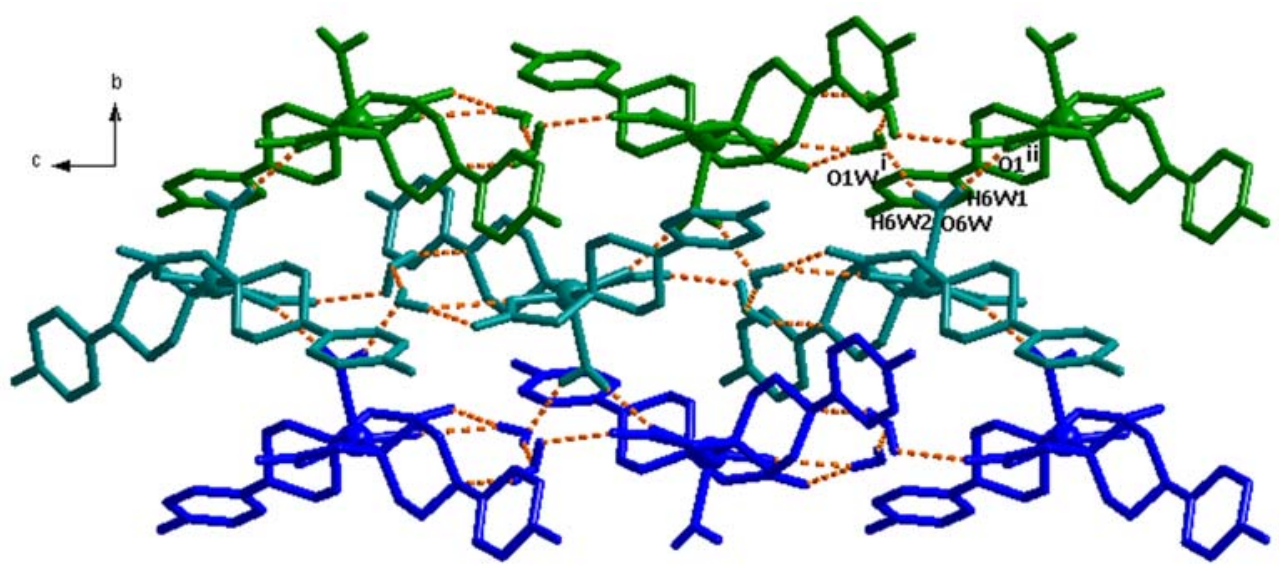

Fig. 3. The hydrogen-bond-driven $2 \mathrm{D}$ sheet of $\mathbf{1}$ extended in crystallographic $b c$ plane. [Symmetry codes: (i) $x, y-1, z ;$ (ii) $-x+1, y-1 / 2,-z+3 / 2$ ] 


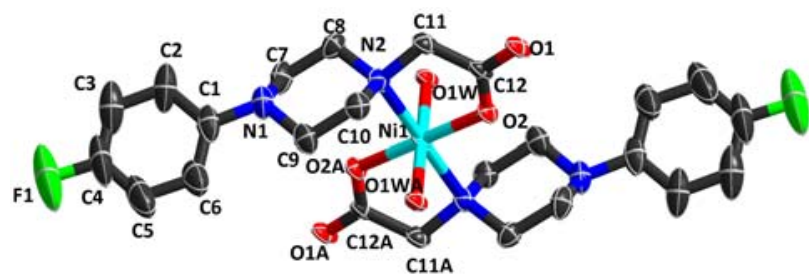

Fig. 4. Molecular diagram for complex 2 showing the atom-labeling scheme. The hydrogen atoms are omitted for clarity. Displacement ellipsoids are drawn at the 50\% probability level.
$\mathrm{O} 1 \mathrm{~W}-\mathrm{H} 1 \mathrm{~W} 2 \cdots \mathrm{O} 1^{\text {vii }}$ and $\mathrm{O} 1 \mathrm{WA}-\mathrm{H} 1 \mathrm{~W} 2 \mathrm{~A} \cdots \mathrm{O} 1 \mathrm{~A}^{\mathrm{vii}}$ (symmetry code: (vii) $x, y+1, z$ ) hydrogen bonding interaction, leading to the construction of $2 \mathrm{D}$ supramolecular sheet in the $a b$ plane (Figure 6).

\section{3. Inhibitory Activity Against Jack Bean Urease}

The inhibiting urease abilities of the HL and complexes $\mathbf{1}$ and $\mathbf{2}$ were studied based on the literature repor-

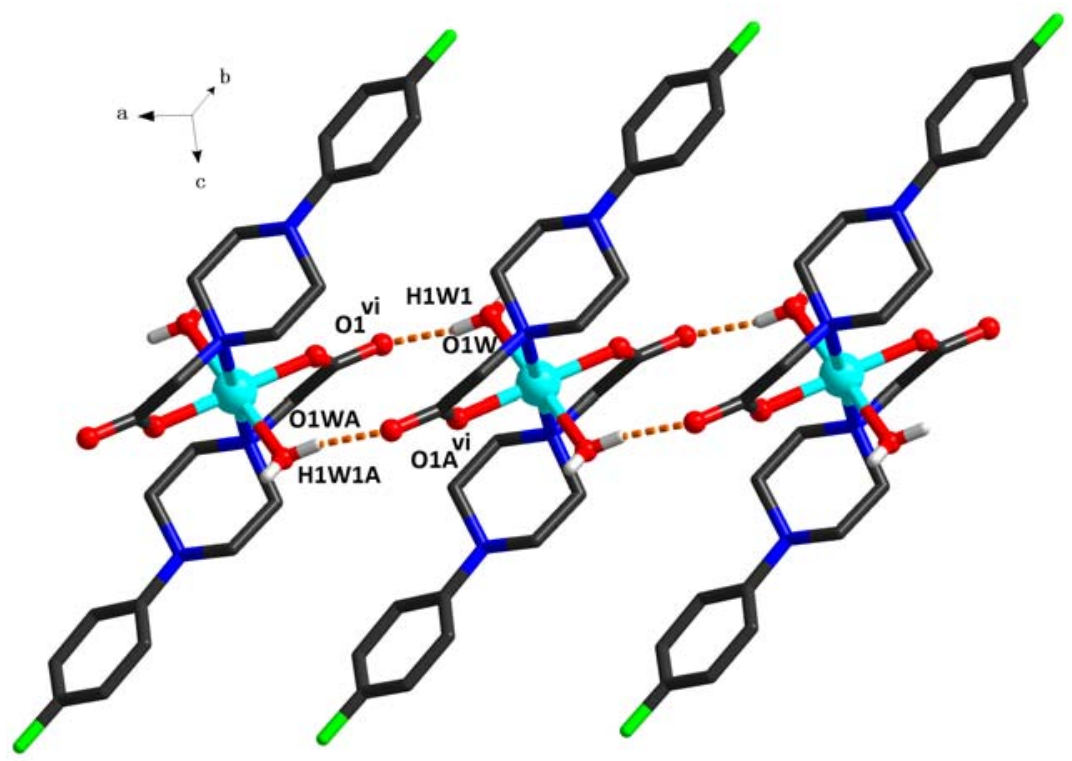

Fig. 5. The hydrogen-bond-driven 1D chain extended in crystallographic $a$ axis of 2. [Symmetry codes: (vi) $-x+2,-y,-z+1$ ]

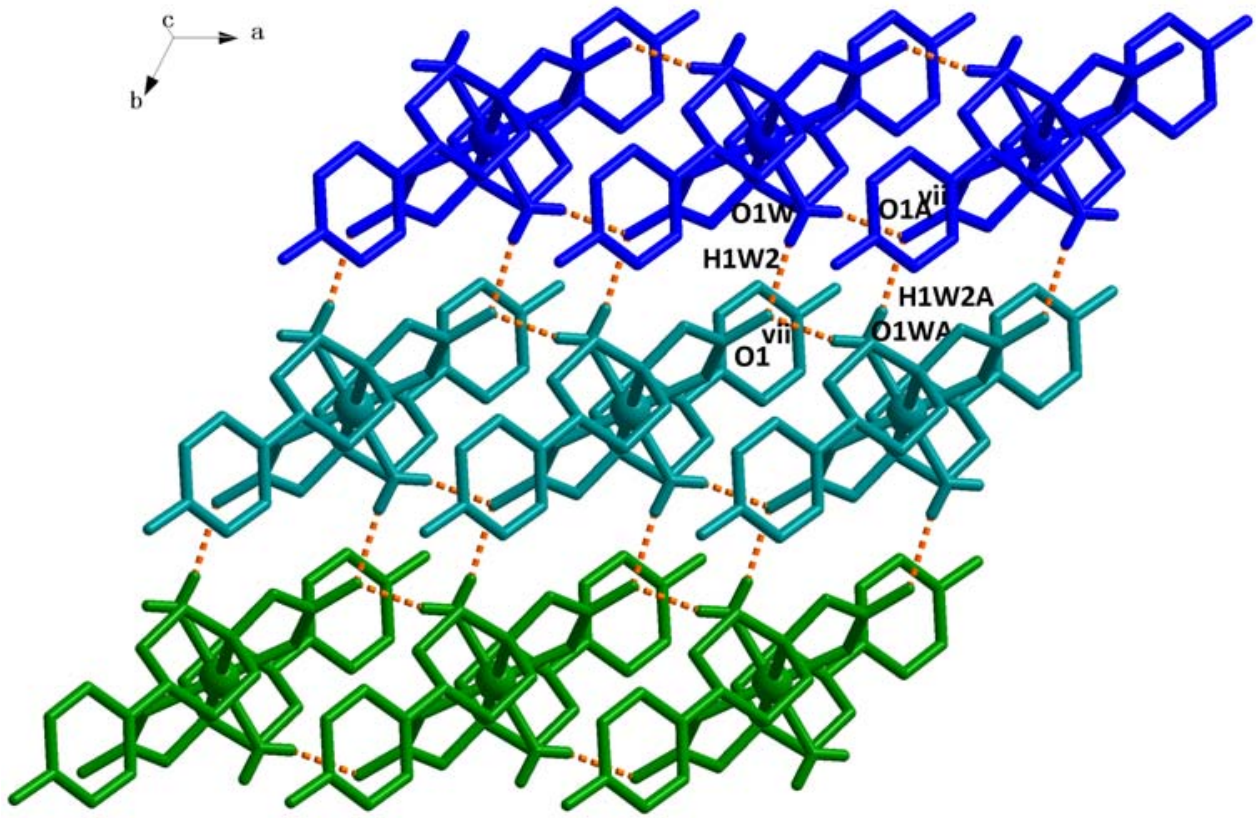

Fig. 6. The hydrogen-bond-driven 2D sheet of $\mathbf{2}$ extended in crystallographic $a b$ plane. [Symmetry codes: (vii) $x, y+1, z$ ] 
ted phenol red method against jack bean urease. The results are summarized in Table 4. It was found that comparing to the ase reference acetohydroxamic acid (AHA, $\mathrm{IC}_{50}=26.99 \pm 1.43 \mu \mathrm{M}$ ), copper ion and nickel ion as salt showed $\mathrm{IC}_{50}$ value of $1.71 \pm 0.56 \mu \mathrm{M}$ and $8.01 \pm 1.21 \mu \mathrm{M}$, while HL and complex 2 exhibited no urease inhibitory activities. Interestingly, compared with recently reported urease inhibition study by others in our group, we found that the urease inhibitory activity of HL was weaker than that of organic compounds synthesized by Sheng and coworkers. ${ }^{27}$ However, after coordinated with copper ion, the inhibitory activity improved distinctly. In addition, compared with other antiurease research by coordinated $\mathrm{Cu}$ (II) ion $\left(0.14 \mu \mathrm{M}\right.$ by Sheng, ${ }^{28} 0.46 \mu \mathrm{M}$ by $\mathrm{Wu}^{29}$ and $22.40 \pm 0.08 \mu \mathrm{M}$ by You $\left.^{30}\right)$, complex 1 showed similar or even better activities against urease, which resulted in the improved inhibitory activity. The result indicated that inhibitory activities of metal complexes were influenced by ligand substituents, electronic configurations, and by the nature of metal center.

Table 4. Inhibition of jack bean urease by the tested materials

\begin{tabular}{cc}
\hline Tested materials & $\mathbf{I C}_{\mathbf{5 0}}(\boldsymbol{\mu} \mathbf{M})$ \\
\hline $\mathbf{1}$ & $0.15 \pm 0.08$ \\
$\mathbf{2}$ & $>100$ \\
$\mathbf{H L}$ & $>100$ \\
$\mathrm{Cu}\left(\mathrm{NO}_{3}\right)_{2} \cdot 3 \mathrm{H}_{2} \mathrm{O}$ & $1.71 \pm 0.56$ \\
$\mathrm{Ni}\left(\mathrm{NO}_{3}\right)_{2} \cdot 6 \mathrm{H}_{2} \mathrm{O}$ & $8.01 \pm 1.21$ \\
$\mathrm{AHA} *$ & $26.99 \pm 1.43$ \\
\hline
\end{tabular}

* Used as a positive control.

\section{4. Molecular Docking}

To find out feasible urea enzyme inhibitors, molecular docking of complexes 1 and $\mathbf{2}$ with 3LA4 was simulated with the AUTODOCK 4.2 program. Additional interactions have been established in a variety of conformations because of the flexibilities of the amino acid residues of jack bean urease. The results indicate that $\mathbf{1}$ may have interaction with 3LA4 as reflected by the binding energy of the amino acid residues with the corresponding complex 1 showed $-2.22 \mathrm{kcal} / \mathrm{mol}$, while complex 2 showed $+46.71 \mathrm{kcal} / \mathrm{mol}$. The optimized cluster $(50$ occurrences) was ranked by energy level in the best conformation of the inhibitor-urease modeled structures, where the lowest intermolecular energy showed $-3.15 \mathrm{kcal} / \mathrm{mol}$.

The binding model of complex 1 with urease (3LA4) is presented in Figure 7 and 8. All the amino acid residues which had interacted with complex 1 were showed. In the binding model, the $\mathrm{O}$ atom of $\mathbf{1}$ as acceptor received one strong hydrogen bonding interaction with Gln635. The hydrogen-bonding distance of Gln635 $\mathrm{N}-\mathrm{H}] \mathrm{O} 8$ was $2.618 \AA$. In addition, Polar interaction exists between the benzene ring of complex 1 and the amino acid (Arg439 and Arg639). The results of the molecular docking indicated that the complex $\mathbf{1}$ could be well fitted in the active pocket of jack bean urease.

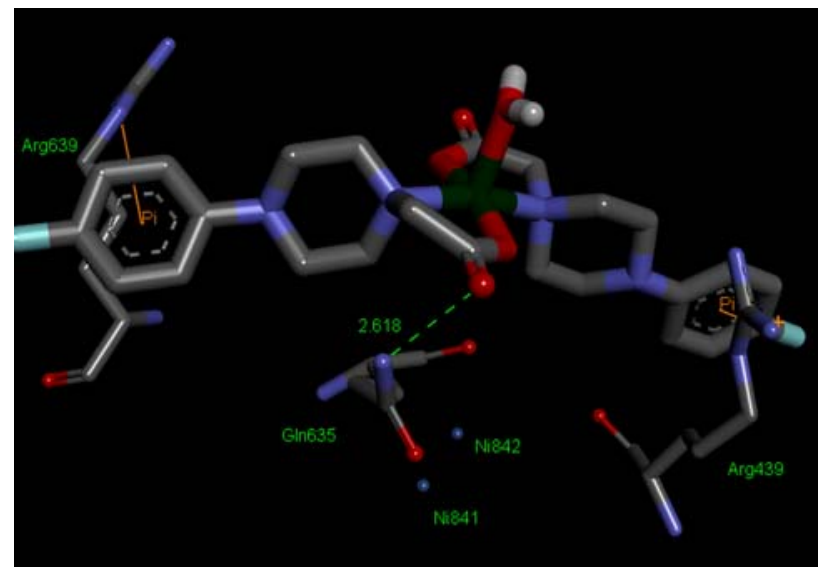

Fig. 7. Modeled structures of complex 1 with jack bean urease. Hydrogen bonds are presented as light green dotted lines.

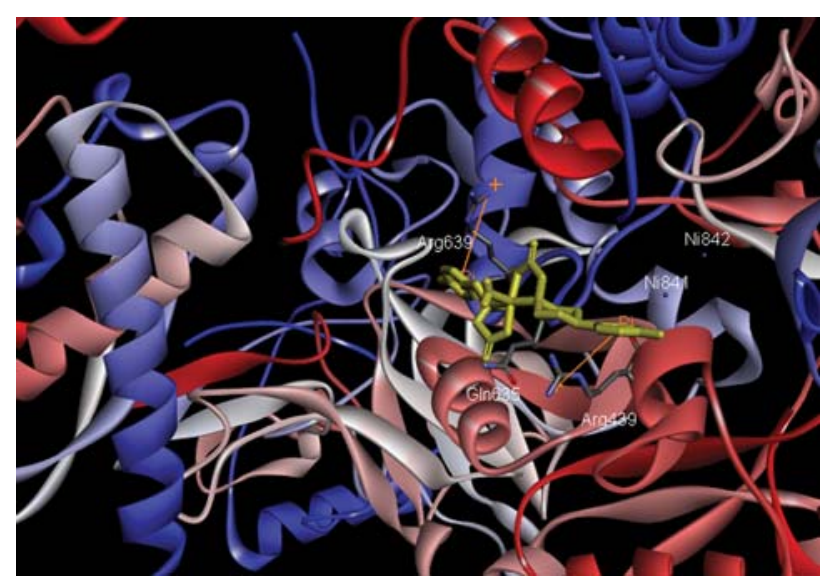

Fig. 8. Binding mode of complex 1 with jack bean urease. The enzyme is shown as Flat Ribbon. The complex is shown as yellow sticks.

\section{Conclusion}

This paper reports the synthesis, crystal structures, urease inhibitory activities and molecular docking of two transition metal complexes with 1-(4-fluorophenyl) piperazine acetic acid ligand. The molecular docking and the urease inhibitory activity studies of the complexes against jack bean urease valuably lead to the development of new urease inhibitors. The inhibitory activity tested in vitro against jack bean urease exhibits that complex 1 displays the best inhibitory activity of $\mathrm{IC}_{50} 0.15 \pm 0.08 \mu \mathrm{M}$. Importantly, we only focused on finding more effective and potent urease inhibitors for structure-activity relationship research of the complexes $\mathbf{1}$ and $\mathbf{2}$, detailed researches are continuing to explore the toxicity of these complexes of urease inhibitory activity for the environment and humans. 


\section{Supplementary Information}

CCDC files 1432471 (1) and 1432470 (2) contain the supplementary crystallographic data for this paper. These data can be obtained free of charge from The Cambridge Crystallographic Data Centre via www.ccdc.cam. ac.uk/ data_request/cif.

\section{Referance}

1. P. A. Karplus, M. A. Pearson, R. P. Hausinger, Acc. Chem. Res. 1997, 30, 330-337.

http://dx.doi.org/10.1021/ar960022j

2. J. B. Sumner, J. Biol. Chem. 1926, 69, 435-441.

3. B. Krajewska, J. Mol. Catal B: Enzym. 2009, 59, 9-21. http://dx.doi.org/10.1016/j.molcatb.2009.01.003

4. C. Follmer, Phytochemistry 2008, 69, 18-28. http://dx.doi.org/10.1016/j.phytochem.2007.06.034

5. K. Stingl, K. Altendorf, E. P. Bakker, Trends Microbiol. 2002, 10, 70-74. http://dx.doi.org/10.1016/S0966-842X(01)02287-9

6. H. Zaheer-ul, M. A. Lodhi, S. Ahmad Nawaz, S. Iqbal, K. Mohammed Khan, B. M. Rode, R. Attaur, M. I. Choudhary, Bioorg. Med. Chem. 2008, 16, 3456-3461. http://dx.doi.org/10.1016/j.bmc.2005.09.048

7. S. Futagami, H. Takahashi, Y. Norose, K. Nagata, M. Kobayashi, T. Nomura, Jpn. Soc. Gastroenterol. 1994, 91, 2202 2213.

8. T. Tanaka, M. Kawase, S. Tani, Life Sci. 2003, 73, 29852990. http://dx.doi.org/10.1016/S0024-3205(03)00708-2

9. H. L. T. Mobley, R. P. Hausinger, Microbiol. Rev. 1989, 53, 85-108.

10. H. L. T. Mobley, M. D. Island, R. P. Hausinger, Microbiol. Rev. 1995, 59, 451-480.

11. M. Negar, S. Parastoo, G. Ameneh, A. Hassan, A. Farzaneh, E. Najmeh, S. Farideh, F. Alireza, S. Abbas, DARU J. Pharmaceut. Sci. 2013, 21, 66-73.

12. C. T. Sadashiva, S. C. J. N. Narendra, K. C. Ponnappa, G. T. Veerabasappa, K. S. Rangappa, Bioorg. Med. Chem. Lett. 2006, 16, 3932-3936.

http://dx.doi.org/10.1016/j.bmcl.2006.05.030

13. A. Tarraga, P. Molina, D. Curiel, J. L. Lopez, M. D. Velasco, Tetrahedron 1999, 55, 14701-14718. http://dx.doi.org/10.1016/S0040-4020(99)00916-3
14. Bruker, SMART (Version 5.63), SAINT (Version 6.02), SADABS (Version 2.03), Bruker AXS Inc. 2002, Madison, Wisconsin, USA.

15. Z. L. You, L. L. Ni, D. H. Shi, S. Bai, Eur. J. Med. Chem. 2010, 45, 3196-3199. http://dx.doi.org/10.1016/j.ejmech.2010.03.012

16. T. Tanaka, M. Kawase, S. Tani, Life. Sci. 2003, 73, 29852990. http://dx.doi.org/10.1016/S0024-3205(03)00708-2

17. D. D. Van Slyke, R. M. Archibald, J. Biol. Chem. 1944, 154, 623-624.

18. F. Musiani, E. Arnofi, R. Casadio, S. Ciurli, J. Biol. Inorg. Chem. 2001, 6, 300-314. http://dx.doi.org/10.1007/s007750000204

19. I. Turel, J. Kljun, Curr. Top. Med. Chem. 2011, 11, 26612687. http://dx.doi.org/10.2174/156802611798040787

20. X. Y. Chen, C. Plasencia, Y. Hou, N. Neamati, J. Med. Chem. 2005, 48, 1098-1106. http://dx.doi.org/10.1021/jm049165z

21. J. Qin, F. X. Li, L. Xue, N. Lei, Q. L. Ren, D. Y. Wang, H. L. Zhu, Acta. Chim. Slov. 2014, 61, 170-176.

22. A. W. Addison, T. N. Rao, J. Reedijk, J. van Rijn, G. C. Verschoor, J. Chem. Soc. Dalton Trans. 1984, 1349-1356. http://dx.doi.org/10.1039/dt9840001349

23. H. Y. Luo, J. M. Lo, E. F. Phillip, G. Joseph, Stowell, A. G. Mark, Inorg. Chem. 1999, 38, 2071-2078. http://dx.doi.org/10.1021/ic981324f

24. A. A. El-Sherif, M. R. Shehata, M. M. Shoukry, M. H. Barakat, Spectrochim. Acta A. 2012, 96, 889-897. http://dx.doi.org/10.1016/j.saa.2012.07.047

25. K. Kubono, Y. Tsuno, K. Tani, K. Yokoi, Acta. Cryst. 2010 , E66, m1397-m1398.

26. R. Melenkivitz, D. J. Mindiola, G. L. Hillhouse, J. Am. Chem. Soc. 2002, 124, 3846-3847. http://dx.doi.org/10.1021/ja017787t

27. G. H. Sheng, X. F. Chen, J. Li, J. Chen, Y. Xu, Y. W. Han, T. Yang, Z. L. You, H. L. Zhu, Acta. Chim. Slov. 2015, 62, 940-946. http://dx.doi.org/10.17344/acsi.2015.1770

28. G. H. Sheng, Q. C. Zhou, X. M. Hu, D. Xue, K. Yan, S. S. Ding, X. F. Chen, C. F. Wang, J. Wang, Z. Y. Du, Z. H. Liu, C. Y. Zhang, H. L. Zhu, J. Coord. Chem. 2015, 68, 15711582. http://dx.doi.org/10.1080/00958972.2015.1023718

29. W. Chen, Y. G. Li, Y. M. Cui, X. Zhang, H. L. Zhu, Q. F. Zeng, Eur. J. Med. Chem. 2010, 45, 4473-4478. http://dx.doi.org/10.1016/j.ejmech.2010.07.007

30. Z. L. You, L. L. Ni, D. H. Shi, S. Bai, Eur. J. Med. Chem. 2010, 45, 3196-3199. http://dx.doi.org/10.1016/j.ejmech.2010.03.012

\section{Povzetek}

Sintetizirana in strukturno okarakterizirana $\mathrm{z}$ rentgensko monokristalno difrakcijo sta dva nova enojedrna kompleksa, $\left[\mathrm{Cu}(\mathbf{L})_{2}\left(\mathrm{H}_{2} \mathrm{O}\right)\right] \cdot 2 \mathrm{H}_{2} \mathrm{O}(\mathbf{1})$ in $\left[\mathrm{Ni}(\mathbf{L})_{2}\left(\mathrm{H}_{2} \mathrm{O}\right)_{2}\right](\mathbf{2})(\mathbf{H L}=2$-[4-(4-fluorofenil)piperazin-1-il]ocetna kislina). Inhibitorna aktivnost teh dveh spojin je bila testirana in vitro na ureazi stročnicoe Canavalia ensiformis. Z molekulskim dockingom so bila raziskani možni vezavni načini. Eksperimentalni podatki in docking simulacije kažejo, da ima kompleks 1 večjo in-

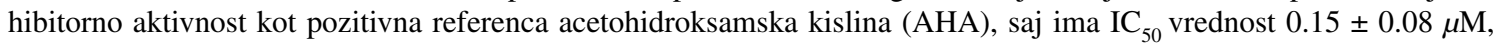
medtem ko spojina 2 ne izraža nobene inhibitorne aktivnosti. 